Research Article

\title{
High Altitudinal Vegetation Dynamics Including Treeline Ecotone in Langtang National Park, Nepal
}

\author{
Binod Baniya ${ }^{1,2, *}$, Narayan Prasad Gaire ${ }^{1}$, Qua-anan Techato ${ }^{2}$, Yubraj Dhakal ${ }^{1}$, Yam Prasad Dhital ${ }^{3}$ \\ ${ }^{1}$ Department of Environmental Science, Patan Multiple Campus, Tribhuvan University, 44618 Nepal \\ ${ }^{2}$ Faculty of Environmental Management, Princes of Songkla University, Hatyai, 90112 Thailand \\ ${ }^{3}$ Institute of Eco-chongming, Faculty of Earth Science, East China Normal University, Shanghai, China \\ (Received: 13 April 2021; Revised: 12 August 2021; Accepted: 25 August 2021)
}

\begin{abstract}
Identification of high altitudinal vegetation dynamics using remote sensing is important because of the complex topography and environment in the Himalayas. Langtang National Park is the first Himalayan park in Nepal representing the best area to study vegetation change in the central Himalaya region because of the high altitudinal gradient and relatively less disturbed region. This study aimed at mapping vegetation in Langtang National Park and its treeline ecotone using Moderate Resolution Imaging Spectroradiometer (MODIS), Normalized Difference Vegetation Index (NDVI). Two treeline sites with an altitude of 3927 and 3802 meters above sea level (masl) were selected, and species density was measured during the field survey. The linear slope for each pixel and the Mann Kendall test to measure significant trends were used. The results showed that NDVI has significantly increased at the rate of $0.002 \mathrm{yr}^{-1}$ in Langtang National Park and $0.003 \mathrm{yr}^{-1}$ in treeline ecotone during 2000-2017. The average $68.73 \%$ equivalents to $1463 \mathrm{~km}^{2}$ of Langtang National Park are covered by vegetation. At the same time, $16.45 \%$ equivalents to $350.43 \mathrm{~km}^{2}$ are greening, and $0.25 \%$, i.e., $5.43 \mathrm{~km}^{2}$ are found browning. In treeline ecotone, the vegetation is mostly occupied by grasses, shrublands and small trees where the NDVI was found from 0.1 to 0.5 . The relative changes of NDVI in barren lands are negative and vegetative lands above $0.5 \mathrm{NDVI}$ are positive between 2000 and 2017. The dominant treeline vegetation were Abies spectabilis, Rhododendron campanulatum, Betula utilis and Sorbus microphyla, with the vegetation density of 839.28 and 775 individuals per hectare in sites $A$ and $B$, respectively. The higher average NDVI values, significantly increased NDVI, and higher density of vegetation in both $A$ and $B$ sites indicate that the vegetation in treeline ecotone is obtaining a good environment in the Himalayas of Nepal.
\end{abstract}

Keywords: Langtang National Park, NDVI, treeline ecotone, vegetation greenness

\section{Introduction}

Vegetation changes have been widely investigated using both ground and satellite-based observation. In-situ monitoring, surface and remote sensing approaches provide information on surface vegetation changes at varying temporal and spatial scales (Chen et al. 2019; Wang et al. 2019). Among these, satellite imagery has potentially emerged to study vegetation changes on a large spatial scale (Kerr \& Ostrovsky 2003). The satellitederived Normalized Difference Vegetation Index (NDVI) is used as a proxy indicator of the vegetation changes. Thus, vegetation dynamics at local, regional, national and global scales are identified using NDVI (Chen et al., 2014; Gang et al., 2016; Kong et al., 2017; Panday \& Ghimire, 2012; Piao et al., 2015; Wang et al., 2017; Zhong et al., 2010). The global monitoring of NDVI is used to predict the ecological effects of environmental changes, directly influencing on structure and functioning of the ecosystem (Pettorelli et al., 2005). The NDVI has shown a consistent correlation with vegetation biomass and dynamics in various ecosystems worldwide (Myneni et al., 1995; Running, 1990) because the NDVI correlates directly with the vegetation productivity (Reed et al., 1994). The NDVI provides information about the spatial and temporal distribution of vegetation communities (Reed et al., 1994), $\mathrm{CO}_{2}$ fluxes (Vourlitis et al., 2003; Wylie et al., 2003), land degradation in a various ecosystem (Bai et al., 2008; Holm et al., 2003; Thiam, 2003), forest carbon dynamics(Dong et al., 2003; Myneni et al., 2001; Piao et al., 2005), land use and land cover (He et al., 2017), identification of drought (Deng et al., 2013; Domenikiotis et al., 2004; Liang et al., 2017; Qian et al., 2016), fire (Maselli et al., 2003), flood (Wang et al., 2003) and frost (Tait \& Zheng, 2003).

The NDVI is the ratio of the difference between the near-infrared and red visible bands and the sum of these two bands (Rouse et al. 1974; Tucker, 1979). It depends on chlorophyll pigments in which healthy plants absorb more visible light indicating more photosynthesis activities and productivity. The NDVI values range between -1 to +1 , whereas the NDVI value increases with increase in the greenery of the forest, grasses, shrub and croplands (Tucker, 1979). The NDVI is used for vegetation mapping, in which more than 0.1 NDVI represents vegetation (Fang et al., 2004; Zhou et al., 2001). Recently, vegetation studies have also found focusing on the Himalaya (Anderson et al., 2020; Mishra \& Mainali, 2017; Paudel \& Peter, 2010).

The highest altitudinal limit of the forests separated from alpine or tundra vegetation is commonly referred to as treeline representing high elevation vegetation zones. It is

Corresponding author: binod.baniya@pmc.tu.edu.np; Tel: +977-9841832743; Kathmandu, 44618, Nepal 
found as the upper altitudinal or latitudinal limit in which upright trees reach either two or three meters in height (Gaire et al., 2014; Harsch et al., 2009; Körner \& Paulsen, 2004; Schickhoff et al., 2016). The treeline ecotone in the Nepal Himalaya is characterized as climatic (natural), orographic (topography) and anthropogenic (Gaire et al., 2014).

The alpine vegetation is an important indicator of the environmental changes, which shows a quick response to the climate and other bio-physical environmental changes (Shrestha et al., 2012). As the climate has warmed, many treelines around the planet have shifted upwards (Gaire et al., 2014; Greenwood \& Jump, 2014; Harsch et al., 2009) and few of them are stable as well. The diverse topography, biodiversity, treeline form and human influences make the Himalaya complex where treeline vegetation are changing their spatial ecological niche $\mathrm{Xu}$ \& Grumbine, 2014). The mountain region of Nepal is dominated by high altitudinal needle-leaved open and closed forest which are mainly evergreen forests such as Pine forest (Blue pine, Chir pine), Birch-Rhododendron, Fir-Hemlock-Maple, Oak-Laurel, Mountain OakRhododendron forest, Juniper, Larch and some deciduous evergreen forest (MENRIS/ICIMOD, 2008). These vegetation growths and distribution in treeline ecotone of the alpine regions have been rapidly changing in response to the environment over time, which refers to treeline dynamics or treeline vegetation dynamics. Abies spectabilis (Himalayan Silver fir), Betula utilis (Himalayan birch) and Pinus wallichiana (Himalayan blue pine) are the dominant treeline species in Nepal Himalaya (Chhetri et al., 2017). Abies spectabilis cover treeline ecotone ranging from 3800 to $4100 \mathrm{~m}$ above sea level (masl) (Chhetri \& Cairns, 2015; Chhetri \& Cairns, 2016). In the Trans-himalayan regions of Nepal, the treeline ecotone occurs between 3800-4100 $\mathrm{m}$ and is dominated by Betula utilis and Abies spectabilis with few presence of Pinus wallichiana (Tiwari et al., 2017a; Tiwari et al., 2017b). In central Nepal, treeline forming vegetation is associated with Rhododendron campanulatum (bell rhododendron) and Juniperus indica (black juniper). Several previous studies have shown the treeline response to climate changes over the limited area of the Nepal Himalaya (Chhetri \& Cairns, 2015; Gaire et al., 2014; Kharal et al., 2017; Shrestha et al., 2017; Sigdel et al., 2018; Thapa et al., 2017; Tiwari et al., 2017a). Few studies of modeling have also been conducted for studying treeline vegetation dynamics and habitat distribution of the plant's species (Chhetri et al., 2018; Chhetri et al., 2017; Schickhoff et al., 2015). All of this above-mentioned research were mainly relying on dendrochronological approach and point-scale research.

Langtang National Park (LNP) is the first Himalayan protected area in Nepal. It experiences a wide range of climate and diverse vegetation types because of high altitudinal gradient ranging from 792 to $7,245 \mathrm{~m}$ a.s.l. In the meantime, the area is less disturbed. Very few studies have been carried in this region using satellite- derived NDVI data. The study of spatio-temporal variation of NDVI using MODIS data in Koshi River basin showed increased NDVI (Wu et al., 2020). However, this study covered large areas but not addressed treeline ecotone. In this context, we aimed to study vegetation changes in Langtang National park, and its treeline ecotone (3700$4200 \mathrm{~m})$ using MODIS NDVI images. Finding of vegetation greeness in treeline ecotone using NDVI is another objective of this research. Based on vegetation coverage, treeline vegetation dynamics inside the park were identified and verified using in-situ measurement. Identification of vegetation dynamics in treeline ecotone using NDVI is the first attempt in these region. The areas of maximum average NDVI and significant positive NDVI trends are considered a good habitat of vegetation in treeline ecotone (Baniya et al., 2018).

Remote sensing is a widely used technique for detecting treeline dynamics (Zong et al., 2014). The remote sensing derived NDVI has the privilege to quantify continuous vegetation changes within each pixel. A pixel with few trees might be classified as non-forest during land covers classification, even though it has a higher NDVI value than barren lands. Identification of these changes is very difficult in any classified images, while NDVI can locate it more accurately (Zhang et al., 2009). The field study has been conducted to verify remote sensing based NDVI results, vegetation types in treeline ecotone and altitudinal position of the treeline. The density of treeline vegetation was also estimated in two treeline sites; one faced on South-West, and another faced on South-East direction of the Lauribinayak hill in the park and identified numbers of treeline vegetation per unit of area. This study also seeks the relevancy of remote sensing for vegetation change in high altitudinal regions and treeline ecotone of the Nepal Himalaya. The study incorporates both field observation and remote sensing approach.

\section{Materials and Methods}

\section{Study area}

Langtang National Park is located in North-Central Nepal between $27^{\circ} 57^{\prime}$ and $28^{\circ} 22^{\prime} \mathrm{N}$ to $85^{\circ} 12^{\prime}$ and $85^{\circ} 52^{\prime} \mathrm{E}$. It represents some of the best examples of graded climatic conditions in the Central Himalaya. It is the first Himalayan park within the sacred Himalayan landscape in Nepal, with $2130 \mathrm{~km}^{2}$, including a buffer zone. The elevation gradient is distinct in LNP, which ranges between $7145 \mathrm{~m}$ a.s.l (Lirung) as the highest and $792 \mathrm{~m}$ a.s.l (Bhote Koshi) as the lowest (Chaudhary, 1998). This high altitudinal variation is coupled with unique topography and vegetation. In 2010, the park was mainly occupied by forest $(37.59 \%)$ with a large area of needleleaved, i.e., $35.47 \%$ and $2.12 \%$ broadleaved forest. Similarly, the land use category includes $19.41 \%$ snow/glacier, $16.33 \%$ barren, $17.62 \%$ grasslands, $4.66 \%$ agricultural lands, $4.28 \%$ shrublands, and $0.077 \%$ rivers in 2010 (Uddin et al., 2015) (Fig. 1). The LNP is extended over parts of three districts, namely Rasuwa, Nuwakot and Sindhupalchowk of Bagmati Province (MoFALD, 2017). The main dominant treeline vegetation in LNP is $A$. spectabilis associated with $\mathrm{R}$. campanulatum and J. indica. The treeline was mainly found in between 3700 to 4200 m.a.s.l. in the park (Fig. 1). 


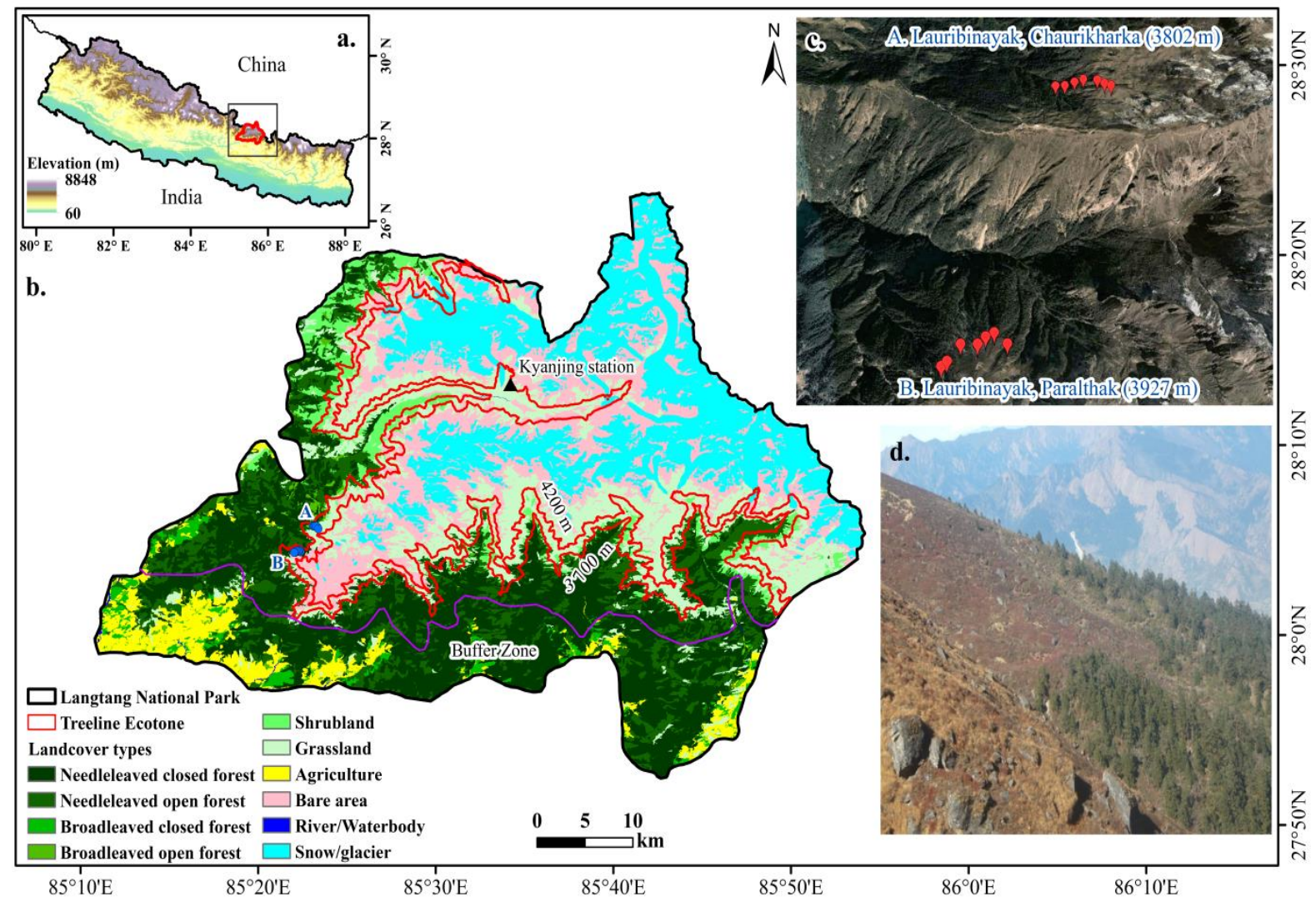

Figure 1 The inset (a) shows the location of the study area with highest altitude of $8848 \mathrm{~m}$ (corrected $8848.86 \mathrm{~m}$ ), i.e., LNP with its land cover (Uddin et al., 2015), treeline ecotone, and filed study sites (b) the left top figure (c) shows the treeline in google image (Sites A and B) whereas left down figure (d) shows treeline in the study area.
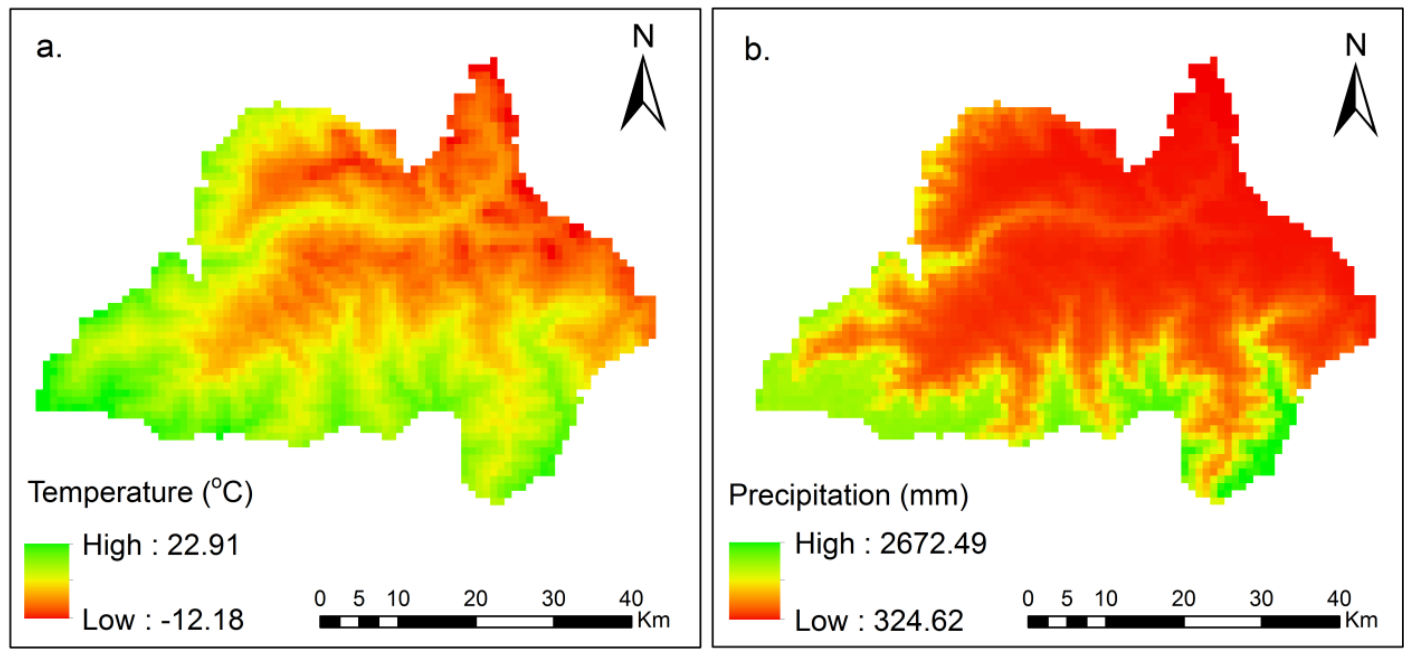

Figure 2 Climatic Research Unit 1km gridded average annual temperature and precipitation during $2000-2017$ at Langtang National Park, Nepal.

The average annual temperature and precipitation data obtained from CRU data during 2000-2017 (Harris et al., 2014) and downscaled to $1 \mathrm{~km}$ (Mosier et al., 2014) in LNP are presented (Fig. 2). The temperature and precipitation are the highest in lower parts of the study area and gradually decreased towards the higher altitude. The nearest meteorological station from the treeline ecotone of the park is situated at Kyanjing (Altitude-3920 m; index no-1031; location- $28^{\circ} 13^{\prime} \mathrm{N}$ and $85^{\circ} 34^{\prime} \mathrm{E}$ ) showed that the average annual temperature was $6.04^{\circ} \mathrm{C}$ with a maximum 
of $12.74{ }^{\circ} \mathrm{C}$, minimum of $0.71{ }^{\circ} \mathrm{C}$, and the average annual precipitation was $545 \mathrm{~mm}$ during 2000-2017(DHM, 2017).

\section{Data and data processing}

The MODIS NDVI, i.e., MOD13Q1 Terra product, was used to study vegetation dynamics (Didan, 2015). The data has 16 days temporal and $250 \mathrm{~m}$ spatial resolution spanning from 2000 to 2017. The noise of NDVI time series datasets was removed using the Savitzky-Golay filter, which provides a simplified least-squares-fit convolution for smoothing and computing derivatives of a set of consecutive values (Savitzky \& Golay, 1964). The auxiliary data such as land use and land cover (Uddin et al., 2015), and Shuttle Radar Topography Mission (SRTM) $30 \mathrm{~m}$ Digital Elevation Model (DEM) (Jarvis et al., 2008) were used. A field study was also conducted in September 2020 for the verification of the results. In LNP, two treeline sites, i.e., Lauribinayak- Chaurikharka (Site A) and Paralthak (Site B), were chosen at an average altitude of $3802 \mathrm{~m}$ and $3927 \mathrm{~m}$ a.s.l, respectively. In the selection of these sites, preference was given in the area that has lesser or no anthropogenic activities and the treeline was selected based on the upper tree limit (at least $2 \mathrm{~m}$ in height).

\section{Data analysis}

Spatial and temporal vegetation changes in LNP during 2000-2017

The annual average NDVI from 2000-2017 was computed from raster image analysis in ArcGIS 10.2. The linear slope of NDVI for each pixel (Baniya et al., 2018; Fensholt \& Proud, 2012; Liu et al., 2015; Piao et al., 2011) and $p$ values for the significant changes using Mann Kendall (Kendall, 1975; Mann, 1945) and Sen's slope (Sen,
1968) test were calculated. Then, the net vegetation changes in LNP and treeline ecotone of the park were identified using the following equation (Baniya et al., 2019).

$$
\text { Net NDVI changes }=\sum_{\mathrm{i}=1}^{\mathrm{n}} \mathrm{N}_{\mathrm{i}} A
$$

where $\mathrm{i}$ represents a pixel with a statistically significant trend, $\mathrm{n}$ is the total number of such pixels, $\mathrm{N}_{\mathrm{i}}$ is the number of pixels in which NDVI is significantly changed, and $A_{i}$ is the pixel area.

\section{Vegetation coverage in treeline ecotone of $L N P$}

The treeline vegetation in LNP was identified based on average NDVI in treeline ecotone. The mean NDVI below 0.1 is not considered as vegetation (Fang et al., 2004; Zhou et al., 2001). Therefore, the higher NDVI denotes higher vegetation presence, i.e., trees, seedlings, and saplings represent a good habitat for treeline vegetation. NDVI provides the direct evidence of the vegetation at any locality. The following four categories of NDVI were used to find the vegetation coverage in the treeline ecotone of LNP in Central Himalaya of Nepal (Baniya et al., 2018) (Table 1).

The NDVI values greater than 0.1 to +1 were categorized as a normal, good and excellentsurface vegetation coverage, respectively. In this study, treeline ecotone was considered between 3700-4200 $\mathrm{m}$ altitude in LNP based on field observation and previous records of treeline altitudinal position found in the Nepal Himalaya (Chhetri \& Cairns, 2015; Chhetri et al., 2018; Gaire et al., 2014; Tiwari et al., 2017a).

Table 1 NDVI categories used to identify greenness of vegetation in treeline ecotone of LNP during 2000-2017.

\begin{tabular}{lll}
\hline Category & NDVI values & Greeness of vegetation \\
\hline 1 & $<0.1$ & Poor \\
2 & $0.1-0.3$ & Normal \\
3 & $0.3-0.5$ & Good \\
4 & $>0.5$ & Excellent \\
\hline
\end{tabular}

\section{Measurement of treeline species density}

The total number of 14 quadrat (7 in each site of having $20 \times 20 \mathrm{~m}$ size) were sampled at two treeline sites. The number of treeline species $(>2 \mathrm{~m}$ ht) that occurred within the quadrat was recorded to find the treeline species density. The density was calculated using the following equation for the practical approach of the vegetation description (Kent \& Coker, 1995)
A horizontal transect of $100 \mathrm{~m}$ was drawn in the treeline, and quadrat were sampled randomly based on treeline species presence in Chaurikharkha and Paralthak treeline sites in the Lauribinayak (Fig. 1). The total number of 7 quadrat of $20 \times 20 \mathrm{~m}$ was sampled in each treeline site. The densities of treeline species were measured to support satellite-derived NDVI and NDVI changes in both treeline sites located in LNP. 


\section{Results and Discussion}

Vegetation dynamics based on MODIS NDVI changes

The spatial average NDVI of all pixels during 2000-2017 in LNP was 0.286 and 0.277 in it's treeline ecotone. The spatial average NDVI has significantly increased at the rate of $0.002 \mathrm{yr}^{-1}$ in LNP and $0.003 \mathrm{yr}^{-1}$ in treeline ecotone during the last 18 years. The spatially averaged temporal vegetation has increased in all the park areas and treeline ecotone of LNP. However, the average NDVI was lower in 2000 and 2004 in the park and 2000, 2004 and 2015 in the treeline ecotone. Similarly, both the park and treeline ecotone showed higher average NDVI in 2009 (Fig. 3). a.

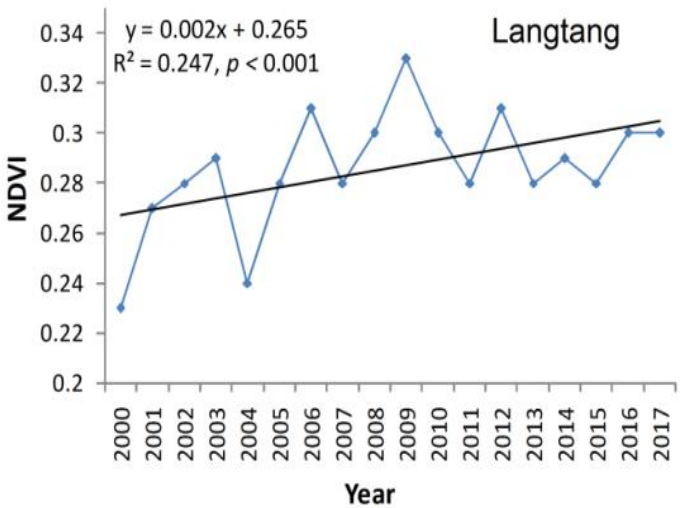

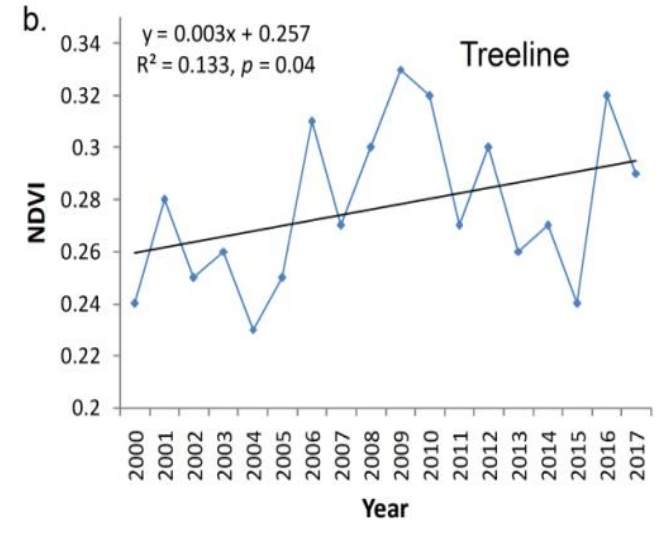

Figure 3 Temporal trends of spatial average NDVI based on Mann Kendell and Sen's slope (a) Langtang National Park and (b) treeline ecotone in Nepal during 2000-2017.
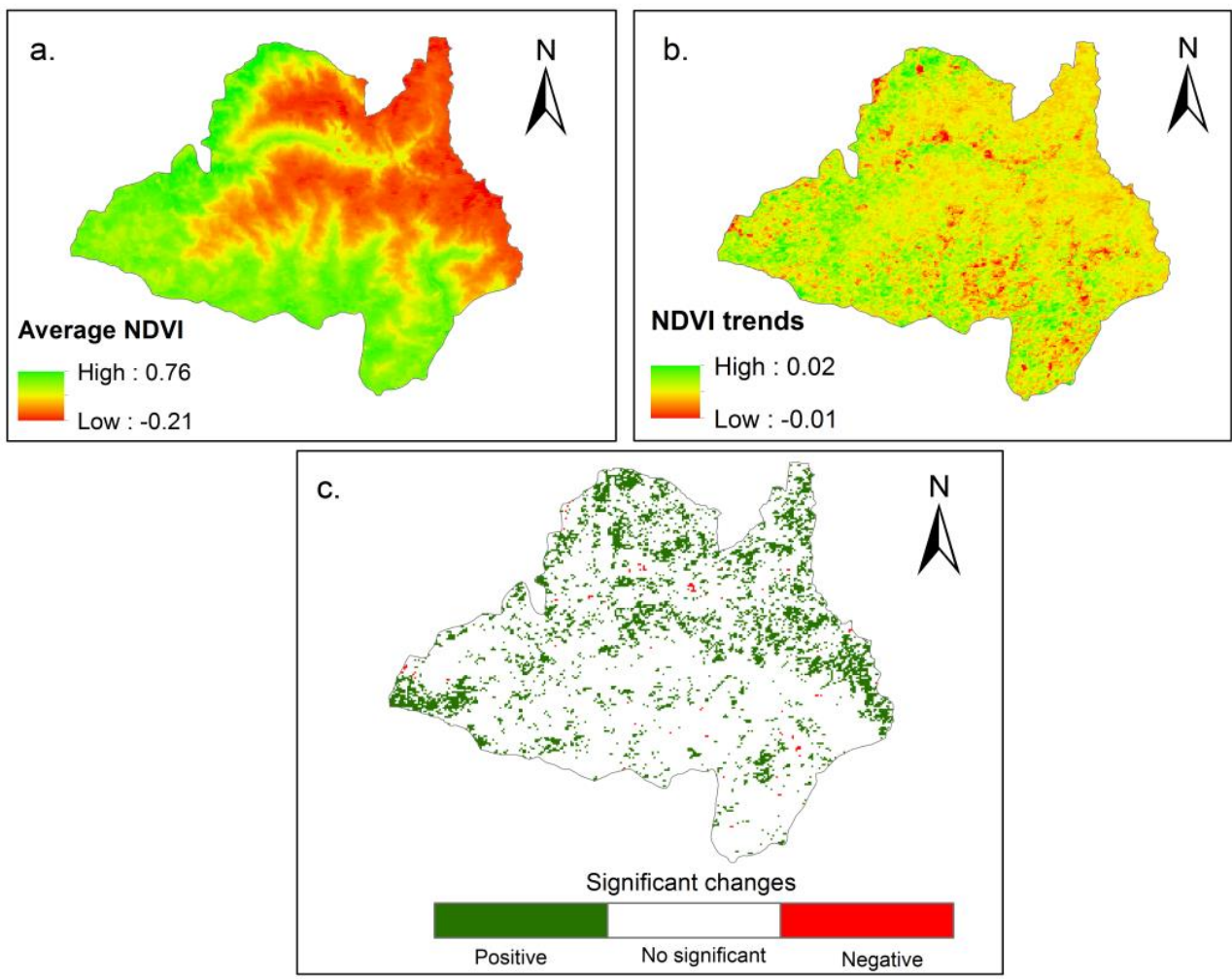

Figure 4 The NDVI and its changes; (a) Spatial distribution of NDVI; (b) Linear NDVI trends and (c) Significant NDVI trends based on Mann Kendall test statistics in each pixel during 2000-2017 in Langtang National Park (Scales: 0$40 \mathrm{Km}$ in each).

A total of $68.73 \%$, equivalent to $1463 \mathrm{~km}^{2}$ areas of LNP, was occupied by vegetation where the average NDVI is more than 0.1. Generally, the lower reaches, including the buffer zone, have good NDVI distribution. However, the areas above the treeline ecotone had an average NDVI less than 0.1 (Fig. 4a). During the last 18 years, $88.05 \%$ equivalent to $1875.56 \mathrm{~km}^{2}$ areas of the park showed positive NDVI trends with significant positive trends in $16.45 \%$ equivalent to $350.43 \mathrm{~km}^{2}$. The average NDVI distribution, trends and significant trends are shown in 
Fig. 4. The significant positive trends are also found in the barren lands above the treeline ecotone (3700-4200 m) of the park (Fig. 4c). Rhododendron campanulatum above treeline were regenerating faster and have had continuous growth (Mainali et al, 2019). A very few areas showed significant negative trends, i.e., only $0.25 \%\left(5.43 \mathrm{~km}^{2}\right)$, mainly in the parts of Rasuwa and Sindupalchowk district of the park. Overall, $16.45 \%$ of the park is greening, i.e., significantly increased NDVI, while $0.25 \%$ is browning, i.e., significantly decreased NDVI during 2000-2017. The maximum positive NDVI trend of $0.02 \mathrm{yr}^{-1}$ and negative NDVI trend of $-0.01 \mathrm{yr}^{-1}$ was found in the park during the last 18 years. The greening trends in large area of the park showed higher number of saplings, seedlings and increased vegetation growth which is a signal of vegetation shift or growth in high altitudinal regions in Nepal.

\section{Identification of vegetation coverage in treeline ecotone}

The treeline vegetation is dominated by $A$. spectabilis and R. campanulatum with associating B. utilis and $S$. microphyla in LNP. The treeline vegetation found good in the western regions of the park located in the Rasuwa district, where the NDVI in the majority of the areas was in the range of 0.3 to 0.5 . The treeline site, i.e., Lauribinayan Chaurikharka $(3802 \mathrm{~m})$ and Paralthak $(3927 \mathrm{~m})$, were found to possess good to an excellent greening where the average NDVI was more than 0.3 and significantly increased in the study period (Fig. 5). Similarly, treeline ecotone at Thangsyap showed good surface greening where the NDVI has significantly increased. The treeline at the southern site of the park located in the Nuwakot district does not have good surface coverage; however, some small areas showed significantly increased NDVI. In Fig. $5 \mathrm{a}$, the green circles indicate the areas with positive NDVI pixels, i.e., good coverage of treeline vegetation, whereas the red circles indicate the areas with negative NDVI pixels, i.e.,poor coverage of vegetation. In Fig. 5, points $\mathrm{A}$ and $\mathrm{B}$ inside the green circles show Lauribinayak Chaurikharka and Lauribinayak Paralthak treeline sites. The treeline in the eastern site of the park located in the Sindhupalchowk district has better vegetation cover and getting improved NDVI compared to the southern parts of the park (Fig. 5).

In the treeline ecotone of the Rasuwa district, some areas located above Deding and Kyanjin in Langtang and Timure have NDVI less than 0.1 representing no vegetation and the tree line above Kyanjin also experienced significantly decreased NDVI. The large portion of treeline areas with mean NDVI between 0.3 to 0.5 and significant NDVI changes showed that these areas have higher regeneration capability, i.e., seedlings and saplings of treeline species. The areas with negative NDVI values were manually checked in Landsat scenes and Google Earth and found that these areas were marked with landslide, avalanches, barren land and tongue of debris-covered glaciers. The significantly increased NDVI (Fig. 5b) showed that large areas of the treeline ecotone are greening and obtaining good vegetation coverage of plant species. The area inside the green circle showed in Fig. 5b were field observation sites where the NDVI has significantly increased that indicates good greening and regeneration potential of treeline vegetation.

The significant NDVI trends were also found above the treeline that reflects the altitudinal shifts of vegetation and land-use conversion from glaciers to the barren land and barren to greening land. The previous study showed that the glacier has been rapidly retreating and decreased in Nepal Himalaya (Bajracharya et al., 2014; Paudel et al., 2016). Consequently, the vegetation shifts to barren lands, and those areas left behind from glacier retreat in the mountain. The high altitudinal vegetation growth and treeline shifting in the mountain (Gaire et al., 2014; Harsch et al., 2009; Schickhoff et al., 2015) supports these results.

The high average NDVI and the areas of positive NDVI trends are considered as good greening of treeline vegetation because the NDVI is the proxy for biomass and productivity (Myneni et al., 1995; Reed et al., 1994) and species richness (Pettorelli et al., 2005). The higher NDVI refers to the dense vegetation and vice versa. The vegetation growth depends on several environmental factors in the Himalaya, such as temperature (Baniya et al., 2018; Gaire et al., 2014; Zhu et al., 2016), $\mathrm{CO}_{2}$ (Krakauer et al., 2017), soil moisture (Tiwari et al., 2017a), human factors and topography (Chhetri et al., 2017). In the Himalaya, rising atmospheric $\mathrm{CO}_{2}$ concentration and nitrogen deposition are the most likely climatic causes of detected greening (Mishra \& Mainali., 2017). The combination of these multiple environmental factors determined the NDVI level. Therefore, good NDVI in favor of these environmental factors provides good habitat and vice versa. The majority of treeline ecotone showed normal to good surface coverage while few ecotone regions showed excellent vegetation coverage. Some treeline sites in upper parts of Lauribinayak, Safru, Bridim, Timure, Langtang, Helambu and Gumba possess excellent coverage of treeline vegetation reflecting good NDVI distribution and significant positive NDVI trends. However, the growth of treeline vegetation depends on aspect, slope and special ecological niche (Schickhoff et al., 2015). Some of the areas in treeline ecotone experienced negative NDVI, indicating inappropriate growth of treeline vegetation. The Deding sites of the Timure, Kyanjin areas of the Langtang and some pixels in the Gumba regions did not show good greening (Fig. 5). These areas are affected both by natural hazards such as snow and glacier cover, landslide, debris covers and rocks, soil avalanche and anthropogenic disturbance like deforestation, forest fire, transhumance and open grazing (Wang et al., 2019). Since thousands of years ago, mountain people have been practicing animal husbandry, timber logging, fodder and firewood collection and transhumance activities in the Nepal Himalaya. Thus, an anthropogenic treeline was formed and dominated in the mountain in which treeline ecotones are transformed at varying extent. Fire and overgrazing are the main cause of treeline vegetation changes in Nepal Himalaya (Wang et al., 2019). The upper regions of the Kyanjin showed negative NDVI (Fig. 5a) due to the deposits of large 
debris/alluvial fan and avalanche, confirmed from Google

Earth visual inspection.
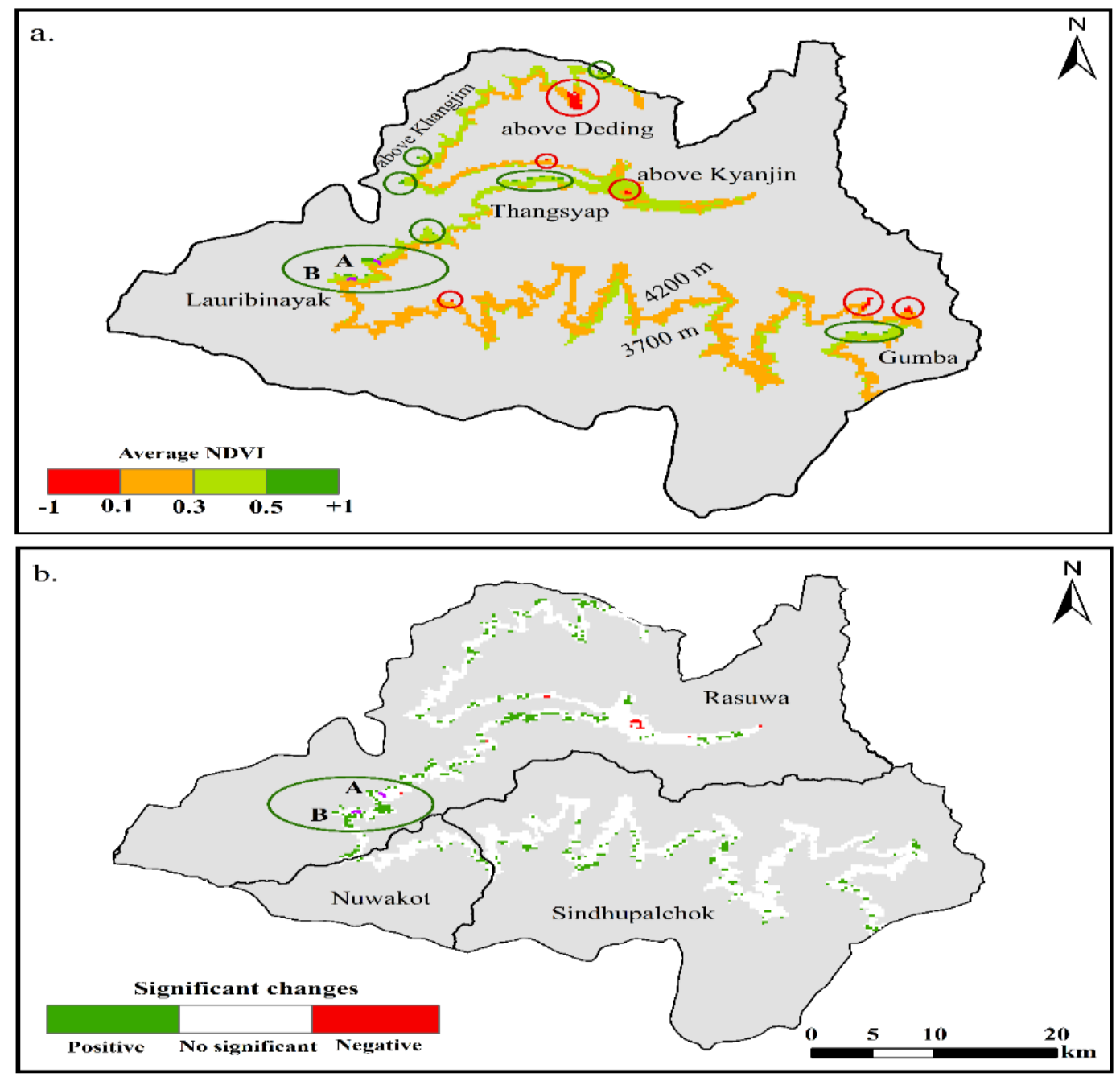

Figure 5: NDVI and NDVI changes in treeline ecotone (a) average NDVI to represent vegetation status and (b) significant NDVI changes in the treeline ecotone

\section{Treeline species density based on the in-situ} measurement

The treeline ecotone was dominated by four treeline species types. The total density of treeline species was 839.28 and 775 individuals per hectare in sites A and B, respectively. The treeline vegetation species such as $R$. campanulatum and $A$. spectabilis, is dominant and highest in number at both sites. These treeline sites $\mathrm{A}$ and $\mathrm{B}$ were found to have good average NDVI (Fig. 5a), significant NDVI change (Fig. 5b) and higher treeline species density. High numbers of seedlings and saplings of $R$. campanulatum were found; however, the saplings of about 1-2 $\mathrm{m}$ height of $A$. spectabilis were dominant in both sites. The density of B. utilis and S. microphylla were lower in both treeline sites. The higher density of $A$. spectabilis and $B$. utilis was found near the timberline (below treeline). Thus, high density of treeline vegetation, good average NDVI and positive NDVI trends in treeline ecotone of altitude between 3700 to $4200 \mathrm{~m}$ a.s.l. showed that treeline vegetation is getting good environment in high altitudinal regions of central Himalaya in Nepal. The density of treeline vegetation species has been calculated for two treeline sites (Site A and B) of LNP (Table 2).

The Pine trees (Chir pine and Blue pine), Oak trees, BirchRhododendron forest, Alpine pasture, Trans Himalayan steppe, Juniper species, Eastern Himalaya Oak-Laurel evergreen coniferous trees are dominated in the park and high altitudinal regions. The major treeline forming species are Fir (A. spectabilis), Birch (B. utilis), Rhododendron forest in the western site, and Oak-Laureal forest in the eastern site of the park are dominant. The majority of the treeline forests are needle-leaved and evergreen forests. Above the treeline, the alpine pasture, dwarf Rhododendron and Juniper scrubs are dominated, which are very important for transhumance, i.e., seasonal droving of the cattle grazing. Beyond the alpine pasture, large areas are nival zone where the vegetation does not exist. Below the treeline, Pine forest, lower temperate Oak forest, Fir trees, and hill Sal with Schima Castapnopsis forest 
are dominant; and some of them being broadleaved and deciduous forest which have distinct phenological periods. The higher density of treeline forming species in both sites supported that the areas are good for treeline vegetation growth and more regeneration capability. The large distribution of the vegetation in the park and treeline ecotone corroborated the results obtained from in-situ (Sites A and B) and remote sensing based NDVI observation. The higher vegetation density, species distribution, NDVI and positive NDVI trends verified that treeline ecotone possesses good surface vegetation coverage and getting good environment of plant growth.

\begin{tabular}{|c|c|c|c|c|c|c|c|c|c|}
\hline \multicolumn{10}{|c|}{ Treeline Site A- Lauribinayak, Chaurikharka } \\
\hline \multirow[t]{2}{*}{ Treeline } & \multicolumn{2}{|c|}{ Coordinates } & \multirow{2}{*}{$\begin{array}{l}\text { Quadrate } \\
\text { size }\end{array}$} & \multicolumn{4}{|c|}{ No of treeline species occurrence } & \multirow{2}{*}{$\begin{array}{c}\text { Total } \\
\text { no. }\end{array}$} & \multirow{2}{*}{$\begin{array}{l}\text { Density } \\
\text { (no/ha) }\end{array}$} \\
\hline & Latitude & Longitude & & A. spectabilis & R. campanulatum & B. Utilis & S. microphylla & & \\
\hline A & 28.09388 & 85.38926 & \multirow{8}{*}{$\begin{array}{l}20 \mathrm{~m} \times \\
20 \mathrm{~m}\end{array}$} & 14 & 16 & 5 & 1 & 36 & \multirow{8}{*}{839.28} \\
\hline B & 28.09465 & 85.38881 & & 12 & 14 & 5 & 3 & 34 & \\
\hline $\mathrm{C}$ & 28.09585 & 85.38481 & & 11 & 15 & 6 & 2 & 34 & \\
\hline D & 28.09564 & 85.38576 & & 9 & 11 & 4 & 4 & 28 & \\
\hline $\mathrm{E}$ & 28.0956 & 85.38678 & & 13 & 11 & 3 & 2 & 29 & \\
\hline $\mathrm{F}$ & 28.09548 & 85.38766 & & 15 & 14 & 3 & 5 & 37 & \\
\hline G & 28.09331 & 85.3897 & & 14 & 17 & 5 & 1 & 37 & \\
\hline \multicolumn{3}{|c|}{ Tree line species density in site $\mathrm{A}$ (no/ha) } & & 314.28 & 350 & 110.71 & 64.28 & 839.28 & \\
\hline \multicolumn{10}{|c|}{ Treeline Site B- Lauribinayak, Paralthak } \\
\hline A & 28.07333 & 85.37305 & \multirow{8}{*}{$\begin{array}{l}20 \mathrm{~m} \times \\
20 \mathrm{~m}\end{array}$} & 14 & 18 & 2 & 2 & 36 & \multirow{8}{*}{775} \\
\hline $\mathrm{B}$ & 28.07444 & 85.37222 & & 9 & 15 & 1 & 4 & 29 & \\
\hline $\mathrm{C}$ & 28.07416 & 85.37138 & & 11 & 13 & 4 & 3 & 31 & \\
\hline $\mathrm{D}$ & 28.07361 & 85.37055 & & 9 & 7 & 6 & 1 & 23 & \\
\hline $\mathrm{E}$ & 28.07388 & 85.36916 & & 12 & 11 & 2 & 4 & 29 & \\
\hline $\mathrm{F}$ & 28.07277 & 85.36777 & & 13 & 14 & 3 & 2 & 32 & \\
\hline G & 28.07250 & 85.36722 & & 11 & 16 & 5 & 5 & 37 & \\
\hline \multicolumn{3}{|c|}{ Tree line species density in site B (no/ha) } & & 282.14 & 335.71 & 82.14 & 75 & 775 & \\
\hline
\end{tabular}

Table 2 Treeline species density (number/ha) in two treeline sites, i.e., Lauribinayak Chaurikharka (Site A) and Lauribinayak Paralthak (Site B) in Langtang National Park of Nepal.

There are some limitations in using MODIS data in LNP, including spatial and temporal resolution (Vermote \& Kaufman, 1995) digital quantization error (Viovy et al., 1992), ground and atmospheric attenuation (Tanre et al., 1992), Sensor quality (Kaufmann et al., 2000) and varied topography. MODIS NDVI is time series and quality controlled (Tucker et al., 2005), effective in vegetation study (Baniya et al., 2018). In addition, the Savitzky-Golay filter was used in MODIS data (Savitzky \& Golay, 1964) for smoothing possible noise obtained from cloud cover, water, snow and shadow. The field data such as finding treeline and quadrate sampling were used for identifying the density of treeline forming species to verify remote sensing approach for NDVI changes. The two treeline sites were only selected during field study because it was not feasible to visit all the treeline sites in rugged, inaccessible and isolated areas in the mountain. In this study, both remote sensing and field data were coupled to make the results more precise.

\section{Conclusion}

This study investigated the vegetation changes in LNP, and its treeline ecotone using MODIS NDVI data. In addition, we also identified surface vegetation coverage in treeline ecotone based on corresponding NDVI values. The field-based treeline species density in two treeline sites were used and supported remote sensing approach. The average NDVI from 2000 to 2017 showed that
$68.73 \%$, equivalent to $1463 \mathrm{~km}^{2}$ areas of Langtang National Park, were covered by vegetation. The average NDVI has significantly increased in LNP and treeline ecotone during the last 18 years. About 16.45\%, equivalent to $350.43 \mathrm{~km}^{2}$ area of the park, was greening during 2000-2017. A large fraction of the treeline areas were possessed normal to good vegetation coverage, whereas few areas showed excellent greening. Most of the treeline ecotone had NDVI greater than 0.1 and significantly increased during the study period. The treeline sites A and B host good to excellent vegetation coverage in which the average NDVI was more than 0.3 and significantly increased. The dominant highlands vegetation is reported $A$. spectabilis, $R$ campanulatum, $B$. utilis, Blue pine and S. microphylla. The vegetation density showed greening and obtaining good environment in treeline ecotone. Meanwhile, good vegetation presence in treeline ecotone indicate that vegetation is shifting towards in higher altitudinal regions. This study implies the relevancy of remote sensing for high altitudinal vegetation dynamics across the Nepal Himalaya in large spatial scales. In future, species-specific vegetation mapping using highresolution satellite data is crucial and factor responsible for high altitudinal vegetation growth are to be determined.

Acknowledgements: The authors would like to thank Institute of Science and Technology, Tribhuvan University, Nepal and Faculty of Environmental 
Management, Princes of Songkla University, Hatyai, Thailand. The authors are also grateful to the Department of National Parks and Wildlife Conservation (DNPWC) and the park office of Langtang National Park, Nepal.

Author Contributions: Conceptualization B.B; writing original draft B.B; N.P.G, Y.D; Writing, review and editing Q.T and Y.P.D. All authors have read thoroughly and agreed to the published version of the manuscript.

Conflict of Interest: The authors declare no conflict of interest.

Data Availability Statement: The data that support the findings of this study are available from the corresponding author, upon reasonable request.

\section{References}

Anderson, Karen, Fawcett, D., Cugulliere, A., Benford, S., Jones, D., \& Leng, R. (2020). Vegetation expansion in the subnival Hindu Kush Himalaya. Global Change Biology, 26(3), 1608-1625.

Bai, Z.G., Dent, D.L., Olsson, L., \& Schaepman, M.E. (2008). Proxy global assessment of land degradation. Soil Use and Management, 24, 223-234.

Bajracharya, S., Maharjan, S., Shrestha, F., Bajracharya, O., \& Baidya, S. (2014). Glacier status in Nepal and decadal changes from 1980 to 2010 based on Landsat data. ICIMOD, Kathmandu, Nepal.

Baniya, B., Tang, Q., Huang, Z., Sun, S., \& Techato, K.-A. (2018). Spatial and temporal variation of NDVI in response to climate change and the implication for carbon dynamics in Nepal. Forest, 9(6), 329. doi 10.3390/f9060329.

Baniya, B., Tang, Q., Pokhrel, Y., \& Xu, X. (2019). Vegetation dynamics and ecosystem service values changes at national and provincial scales in Nepal from 2000 to 2017. Environmental Development, 32, 100464. doi 10.1016/j.envdev.2019.100464.

Chaudhary, R.P. (1998). Biodiversity in Nepal. Tecpress Books 487142, Soi, Wattanasilp, Ratunam, Bangkok, 10400, Thailand.

Chen, B.Z., Xu, G., Coops, N.C., Ciais, P., Innes, J.L., Wang, G.Y., \& Myneni, R.B. (2014). Changes in vegetation photosynthetic activity trends across the Asia-Pacific region over the last three decades. Remote Sensing of Environment, 144, 28-41.

Chen, C., Park, T., Wang, X., Piao, S., Xu, B., Chaturvedi, R., Fuchs, R., Brovkin, V., Ciais, P., Fensholt, R., Tommervik, H., Bala, G., Zhu, Z., Nemani, R.R., \& Myneni, R.B. (2019). China and India lead in greening of the world through land-use management. Nature Sustainability, 2, 122-129.

Chhetri, P.K., \& Cairns, D.M. (2015). Contemporary and historic population structure of Abies spectabilis at treeline in Barun valley, eastern Nepal Himalaya. Journal of Mountain Science, 12, 558-570.

Chhetri, P.K., \& Cairns, D.M. (2016). Dendroclimatic response of Abies spectabilis at treeline ecotone of
Barun Valley, eastern Nepal Himalaya. Journal of Forestry Research, 27, 1163-1170.

Chhetri, P.K., Gaddis, K.D., \& Cairns, D.M. (2018). Predicting the suitable habitat of treeline species in the Nepalese Himalayas under climate change. Mountain Research and Development, 38, 153-163.

Chhetri, P.K., Shrestha, K.B., \& Cairns, D.M. (2017). Topography and human disturbances are major controlling factors in treeline pattern at Barun and Manang area in the Nepal Himalaya. Journal of Mountain Science, 14, 119-127.

Deng, M.X., Di, L.P., Han, W.G., Yagci, A.L., Peng, C.M., \& Heo, G. (2013). Web-service-based Monitoring and Analysis of Global Agricultural Drought. Photogrammetric Engineering and Remote Sensing, 79, 929943.

DHM (2017). Observed climate trend analysis in Nepal (19712014). Department of Hydrology and Meteorology, Kathmandu, Nepal.

Didan, K. (2015). MOD13Q1 MODIS/Terra vegetation indices 16-Day L3 Global 250m SIN V006 (Data set). NASA EOSDIS LP DAAC.

Domenikiotis, C., Spiliotopoulos, M., Tsiros, E., \& Dalezios, N.R. (2004). Early cotton yield assessment by the use of the NOAA/AVHRR derived vegetation condition index (VCI) in Greece. International Journal of Remote Sensing, 25, 2807-2819.

Dong, J.R., Kaufmann, R.K., Myneni, R.B., Tucker, C.J., Kauppi, P.E., \& Liski, J. (2003). Remote sensing estimates of boreal and temperate forest woody biomass: carbon pools, sources, and sinks. Remote Sensing of Environment, 84, 393-410.

Fang, J.Y., Piao, S.L., He, J.S., \& Ma, W.H. (2004). Increasing terrestrial vegetation activity in China, 19821999. Science in China Series C-Life Sciences, 47, 229-240.

Fensholt, R., \& Proud, S.R. (2012). Evaluation of Earth Observation based global long term vegetation trends Comparing GIMMS and MODIS global NDVI time series. Remote Sensing of Environment, 119, 131-147.

Gaire, N.P., Koirala, M., Bhuju, D.R., \& Borgaonkar, H.P. (2014). Treeline dynamics with climate change at the central Nepal Himalaya. Climate of the Past, 10, $1277-$ 1290.

Gang, Y., Zengyun, H., Xi, C., \& Tashpolat, T. (2016). Vegetation dynamics and its response to climate change in Central Asia. Journal of Arid Land, 8(3) 375388.

Greenwood, S., \& Jump, A.S. (2014). Consequences of treeline shifts for the diversity and function of high altitude ecosystems. Arctic Antarctic and Alpine Research, 46, 829-840.

Harsch, M.A., Humle, P.E., McGlone, M.S., \& Duncan, R.P. (2009). Are treelines advancing? A global metaanalysis of treeline response to climate warming. Ecology Letters, 12, 1040-1049.

Harris, I., Jones, P.D., Osborn, T.J., \& Lister, D.H. (2014). Updated high-resolution grids of monthly climatic observations - the CRU TS3.10 dataset. International Journal of Climatology, 34, 623-642. doi10.1002/joc.3711. 
He, Y.Q., Lee, E., \& Warner, T.A. (2017). A time series of annual land use and land cover maps of China from 1982 to 2013 generated using AVHRR GIMMS NDVI3g data. Remote Sensing of Environment, 199, 201217.

Holm, A.M., Cridland, S.W., \& Roderick, M.L. (2003). The use of time-integrated NOAA NDVI data and rainfall to assess landscape degradation in the arid shrubland of Western Australia. Remote Sensing of Environment, 85, 145-158.

Jarvis, S., Reuter, H.I., Nelson, A., \& Guevara, E. (2008). Hole-filled SRTM for the globe Version 4. CGIARCSI SRTM 90 m Database. Retrieved March 4, 2021 from the http://srtm.csi.cgiar.org.

Kaufmann, R.K., Zhou, L.M., Knyazikhin, Y., Shabanov, N.V., Myneni, R.B., \& Tucker, C.J. (2000). Effect of orbital drift and sensor changes on the time series of AVHRR vegetation index data. IEEE Transactions on Geoscience and Remote Sensing, 38, 2584-2597.

Kendall, M.G. (1975). Rank correlation methods. Charles Griffin, London.

Kent, M., \& Coker, P. (1995). Vegetation description and analysis: A practical approach. John Wiley and Sons. New York.

Kerr, J.G., \& Ostrovsky, M. (2003). From space to species: ecological applications for remote sensing. Trends in Ecology \& Evolution, 18(6), 299-305.

Kharal, D.K., Thapa, U.K., St George, S., Meilby, H., Rayamajhi, S., \& Bhuju, D.R. (2017). Tree-climate relations along an elevational transect in Manang Valley, central Nepal. Dendrochronologia, 41, 57-64

Kong, D.D., Zhang, Q., Singh, V.P., \& Shi, P.J. (2017). Seasonal vegetation response to climate change in the Northern Hemisphere (1982-2013). Global and Planetary Change, 148, 1-8.

Körner, C., \& Paulsen, J. (2004). A world-wide study of high altitude treeline temperatures. Journal of Biogeography, 31(5), 713-732.

Krakauer, N.Y., Lakhankar, T., \& Anadon, J.D. (2017). Mapping and attributing normalized difference vegetation index trends for Nepal. Remote Sensing, 9(10), 986. doi 10.3390/rs9100986.

Liang, L., Sun, Q., Luo, X., Wang, J.H., Zhang, L.P., \& Deng, M.X. (2017). Long-term spatial and temporal variations of vegetative drought based on vegetation condition index in China. Ecosphere, 8(8), e01919. doi 10.1002/ecs2.1919.

Liu, X.F., Zhu, X.F., Li, S.S., Liu, Y.X., \& Pan, Y.Z. (2015). Changes in growing season vegetation and their associated driving forces in China during 2001-2012. Remote Sensing, 7, 15517-15535.

Mann, H.B. (1945). Nonparametric tests against trend. Econometrica, 13, 245-259.

Mainali, K., Shrestha, B.B., Sharma, R.K., Adhikari, A., Gurarie, E., Singer, M., \& Parmesan, C. (2020). Contrasting responses to climate change at Himalayan treelines revealed by population demographics of two dominant species. Ecology and Evolution, 10(3), 12091222.

Maselli, F., Romanelli, S., Bottai, L., \& Zipoli, G. (2003). Use of NOAA-AVHRR NDVI images for the estimation of dynamic fire risk in Mediterranean areas. Remote Sensing of Environment, 86, 187-197.

MENRIS/ICIMOD. (2008). Ecology of Nepal, digital polygon data of ecology (elevation and vegetation zones) of Nepal. Mountain Environment Regional Information System (MENRIS), ICIMOD.

Mishra, N.B., \& Mainali, K.P. (2017). Greening and browning of the Himalaya: Spatial patterns and the role of climatic change and human drivers. Science of The Total Environment, 587, 326-339.

MoFALD. (2017). Local Government Operative Act, 2017. Ministry of Federal Affairs and Local Development (MoFALD), Nepal Government, Kathmandu.

Mosier, T.M., Hillb, D.F., \& Sharp, K.V. (2014). 30Arcsecond monthly climate surfaces with global landcoverage. International Journal of Climatology, 34, 2175-2188.

Myneni, R.B., Dong, J., Tucker, C.J., Kaufmann, R.K., Kauppi, P.E., Liski, J., Zhou, L., Alexeyev, V., \& Hughes, M.K. (2001). A large carbon sink in the woody biomass of Northern forests. Proceedings of the National Academy of Sciences, 98, 14784-14789.

Myneni, R.B., Hall, F.G., Sellers, P.J., \& Marshak, A.L. (1995). The interpretation of spectral vegetation indexes. IEEE Transactions on Geoscience and Remote Sensing, 33, 481-486.

Panday, P.K., \& Ghimire, B. (2012). Time-series analysis of NDVI from AVHRR data over the Hindu KushHimalayan region for the period 1982-2006. International Journal of Remote Sensing, 33, 6710-6721.

Paudel, B., Zhang, Y., Wu, X., Li, S., \& Khanal, N. (2016). Review of studies on land use and land cover changes. Nepal Journal of Mountain science, 13(4), 643-660.

Paudel, K.P, \& Peter, A. (2010). Assessing rangeland degradation using multi temporal satellite images and grazing pressure surface model in Upper Mustang, Trans Himalaya, Nepal. Remote Sensing of Environment, 114(8), 1845-1855.

Pettorelli, N., Vik, J.O., Mysterud, A., Gaillard, J.M., Tucker, C.J., \& Stenseth, N.C. (2005). Using the satellite-derived NDVI to assess ecological responses to environmental change. Trends in Ecology \& Evolution, 20, 503-510.

Piao, S.L., Fang, J.Y., Zhu, B., \& Tan, K. (2005). Forest biomass carbon stocks in China over the past 2 decades: Estimation based on integrated inventory and satellite data. Journal of Geophysical Research-Biogeosciences, 110(G1), G01006. doi 10.1029/2005JG000014.

Piao, S.L., Wang, X.H., Ciais, P., Zhu, B., Wang, T., \& Liu, J. (2011). Changes in satellite-derived vegetation growth trend in temperate and boreal Eurasia from 1982 to 2006. Global Change Biology, 17, 3228-3239.

Piao, S.L., Yin, G.D., Tan, J.G., Cheng, L., Huang, M.T., \& Li, Y. (2015). Detection and attribution of vegetation greening trend in China over the last 30 years. Global Change Biology, 21, 1601-1609.

Qian, X.J., Liang, L., Shen, Q., Sun, Q., Zhang, L.P., Liu, Z.X., Zhao, S.H., \& Qin, Z.H. (2016). Drought trends based on the VCI and its correlation with climate factors in the agricultural areas of China from 1982 to 2010. Environmental Monitoring and Assessment, 188(11), 639. 
Reed, B.C., Brown, J.F., VanderZee, D., Loveland, T.R., Merchant, J.W., \& Ohlen, D.O. (1994). Measuring phenological variability from satellite imagery. Journal of Vegetation Science, 5, 703-714.

Rouse, J.J., Haas, R.H., \& J.A., S. (1974). Monitoring vegetation systems in the Great Plains with ERTS. NASA Special Publication, 351, 309-317.

Running, S.W. (1990). Estimating terrestrial primary productivity by combining remote sensing and ecosystem simulation. In R.J. Hobbs, H.A. Mooney (Eds.), Remote Sensing of Biosphere Functioning. Springer, New York, pp. 65-86.

Savitzky, A., \& Golay, M.J. (1964). Smoothing and differentiation of data by simplified least squares procedures. Analytical Chemistry, 36, 1627-1639.

Schickhoff, U., Bobrowski, M., Boehner, J., Buerzle, B., Chaudhary, R.P., Gerlitz, L., Heyken, H., Lange, J., Mueller, M., Scholten, T., Schwab, N., \& Wedegaertner, R. (2015). Do Himalayan treelines respond to recent climate change? An evaluation of sensitivity indicators. Earth System Dynamics, 6, 245-265.

Schickhoff, U., Bobrowski, M., Böhner, J., Bürzle, B., Chaudhary, R., Gerlitz, L., Lange, J., Müller, M., Scholten, T., \& Schwab, N. (2016). Climate change and treeline dynamics in the Himalaya. In R. Singh, U. Schickoff, \& S. Mal (Eds.), Climate Change, Glacier Response, and Vegetation Dynamics in the Himalaya. Springer, pp. 271-306.

Sen, P.K. (1968). Estimate of the regression coefficient based on Kendall's tau. Journal of the American Statistical Associatioin, 63 (324), 1379-1389.

Shrestha, K.B., Chhetri, P.K., \& Bista, R. (2017). Growth responses of Abies spectabilis to climate variations along an elevational gradient in Langtang National Park in the central Himalaya, Nepal. Journal of Forest Research, 22, 274-281.

Shrestha, U.B., Gautam, S., \& Bawa, K.S. (2012). Wide spread Climate Change in the Himalayas and Associated Changes in Local ecosystems. PLOS ONE, 7(5), e36741. doi 10.1371/journal.pone.0036741.

Sigdel, S.R., Wang, Y., Camarero, J.J., Zhu, H., Liang, E., \& Penuelas, J. (2018). Moisture-mediated responsiveness of treeline shifts to global warming in the Himalayas. Global Change Biology, 24(11), 5549-5559.

Tait, A., \& Zheng, X.G. (2003). Mapping frost occurrence using satellite data. Journal of Applied Meteorology, 42, 193-203.

Tanre, D., Holben, B.N., \& Kaufman, Y.J. (1992). Atmospheric correction algorithm for NOAAAVHRR products - theory and applications. IEEE Transactions on Geoscience and Remote Sensing, 30, 231-248.

Thapa, U.K., St George, S., Kharal, D.K., \& Gaire, N.P. (2017). Tree growth across the Nepal Himalaya during the last four centuries. Progress in Physical Geography, 41, 478-495.

Thiam, A.K. (2003). The causes and spatial pattern of land degradation risk in southern Mauritania using multitemporal AVHRR-NDVI imagery and field data. Land Degradation \& Development, 14, 133-142
Tiwari, A., Fan, Z.X., Jump, A.S., Li, S.F., \& Zhou, Z.K. (2017a). Gradual expansion of moisture sensitive Abies spectabilis forest in the Trans-Himalayan zone of central Nepal associated with climate change. Dendrochronologia, 41, 34-43

Tiwari, A., Fan, Z.X., Jump, A.S., \& Zhou, Z.K. (2017b). Warming induced growth decline of Himalayan birch at its lower range edge in a semi-arid region of TransHimalaya, central Nepal. Plant Ecology, 218, 621-633.

Tucker, C., Pinzon, J.E., Brown, M.E., Slayback, D.A., Pak, E., Mahoney, R., Vermote, E.F., \& Saleous, N.E. (2005). An extended AVHRR 8-km NDVI dataset compatible with MODIS and SPOT vegetation NDVI data. International Journal of Remote Sensing, 26(20), 44854498.

Tucker, C.J. (1979). Red and photographic infrared linear combinations for monitoring vegetation. Remote Sensing of Environment, 8, 127-150.

Uddin, K., Shrestha, H.L., Murthy, M.S.R., Bajracharya, B., Shrestha, B., \& Gilani, H. (2015). Development of 2010 national land cover database for the Nepal. Journal of Environmental Management, 148, 82-90.

Vermote, E., \& Kaufman, Y.J. (1995). Absolute calibration of AVHRR visible and near-infrared channels using ocean and cloud views. International Journal of Remote Sensing, 16, 2317-2340.

Viovy, N., Arino, O., \& Belward, A.S. (1992). The best index slope extraction (BISE) - A method for reducing noise in NDVI time-series. International Journal of Remote Sensing, 13, 1585-1590.

Vourlitis, G.L., Verfaillie, J., Oechel, W.C., Hope, A., Stow, D., \& Engstrom, R. (2003). Spatial variation in regional CO2 exchange for the Kuparuk River Basin, Alaska over the summer growing season. Global Change Biology, 9, 930-941.

Wang, Q., Watanabe, M., Hayashi, S., \& Murakami, S. (2003). Using NOAA AVHRR data to assess flood damage in China. Environmental Monitoring and Assessment, 82, 119-148.

Wang, X.Y., Wang, T., Liu, D., Guo, H., Huang, H.B., \& Zhao, Y.T. (2017). Moisture-induced greening of the South Asia over the past three decades. Global Change Biology, 23, 4995-5005.

Wang, Y., Sylvester, S., Lu, X., Dawadi, B., Sigdel, S., Liang, E., \& Camarero, J. (2019). The stability of spruce treelines on the eastern Tibetan Plateau over the last century is explained by pastoral disturbance. Forest Ecology and Management, 442, 34-45.

Wylie, B.K., Johnson, D.A., Laca, E., Saliendra, N.Z., Gilmanov, T.G., Reed, B.C., Tieszen, L.L., \& Worstell, B.B. (2003). Calibration of remotely sensed, coarse resolution NDVI to CO2 fluxes in a sagebrush-steppe ecosystem. Remote Sensing of Environment, 85, 243-255.

Wu, X., Sun, X., Wang, Z., Zhang, Y., Liu, Q., Zhang, B., Paudel, B., \& Xie, F. (2000). Vegetation Changes and Their Response to Global Change Based on NDVI in the Koshi River Basin of Central Himalayas Since 2000. Sustainability, 12, 6644. doi 10.3390/su12166644.

Xu, J.C., \& Grumbine, R.E. (2014). Building ecosystem resilience for climate change adaptation in the Asian 
highlands. Wiley Interdisciplinary Reviews - Climate Change, 5, 709-718.

Zhang, Y.J., Xu, M., Adams, J., \& Wang, X.C. (2009). Can Landsat imagery detect tree line dynamics? International Journal of Remote Sensing, 30, 1327-1340.

Zhong, L., Ma, Y.M., Salama, M.S., \& Su, Z.B. (2010). Assessment of vegetation dynamics and their response to variations in precipitation and temperature in the Tibetan Plateau. Climatic Change, 103, 519-535.

Zhou, L.M., Tucker, C.J., Kaufmann, R.K., Slayback, D., Shabanov, N.V., \& Myneni, R.B. (2001). Variations in northern vegetation activity inferred from satellite data of vegetation index during 1981 to 1999. Journal of Geophysical Research - Atmospheres, 106, 20069-20083.
Zhu, Z.C., Piao, S.L., Myneni, R.B., Huang, M.T., Zeng, Z.Z., Canadell, J.G., Ciais, P., Sitch, S., Friedlingstein, P., Arneth, A., Cao, C.X., Cheng, L., Kato, E., Koven, C., Li, Y., Lian, X., Liu, Y.W., Liu, R.G., Mao, J.F., Pan, Y.Z., Peng, S.S., Penuelas, J., Poulter, B., Pugh, T.A.M., Stocker, B.D., Viovy, N., Wang, X.H., Wang, Y.P., Xiao, Z.Q., Yang, H., Zaehle, S., \& Zeng, N. (2016). Greening of the Earth and its drivers. Nature Climate Change, 6, 791-795.

Zong, S.W., Wu, Z.F., Xu, J.W., Li, M., Gao, X.F., He, H.S., Du, H.B., \& Wang, L. (2014). Current and Potential Tree Locations in Tree Line Ecotone of Changbai Mountains, Northeast China: The Controlling Effects of Topography. PLOS ONE, 9(8), e106114. doi 0.1371/journal.pone.0106114. 